\title{
FABRIKASI HUNIAN SEMENTARA UNTUK PASCA BENCANA
}

(Temporary Shelter Fabrication for Post-disaster)

\author{
Dyah Puspa Ayu', Budi Prayitno², Agus Haryadi² \\ ${ }^{1}$ Mahasiswa Magister Arsitektur, Fakultas Teknik, Universitas Gadjah Mada \\ ${ }^{2}$ Dosen Magister Arsitektur, Fakultas Teknik, Universitas Gadjah Mada \\ Jalan Grafika No. 2 Yogyakarta 55281 \\ dyah.puspa.ayu@gmail.com
}

\begin{abstract}
Indonesia is an inseparable state of the earthquake. As a result of the earthquake, many victims lost their homes. The victims had to stay in isolation for a long time. From that, the victim needs assistance in the form of shelter, but the housing can't be built easily. Then a temporary building is needed a transition phase to house assistance is still being developed. The government is currently unable to provide maximum temporary shelter. The purpose of this study is to find the right model for temporary shelter assistance in post-disaster situations used in refugee locations in Indonesia and abroad. The research method uses a literature review by comparing the temporary shelter model and the study model as a comparison of occupancy dimensions. Temporary shelter is the residence required during post-disaster and can be produced in fabrication. Fabrication for temporary housing is related to connection, material, packaging, demolition, and distribution system. It aims to maximize on-site assistance, facilitating the installation and distribution of temporary shelter.
\end{abstract}

Keywords: temporary shelter, transition phase, fabrication

\section{Abstrak}

Indonesia merupakan negara yang tidak lepas dari bencana gempa. Akibat yang ditimbulkan dari bencana gempa tersebut banyak menelan korban hingga kehilangan tempat tinggal. Para korban terpaksa tinggal dipengungsian dalam waktu lama. Dari itu para korban membutuhkan bantuan berupa hunian, namun hunian tersebut tidak dapat dibangun dengan capat. Maka dibutuhkan bangunan yang bersifat sementara sebagai tahap transisi untuk menuju bantuan hunian tetap terbangun. Pemerintah saat ini belum sanggup memberikan bantunan hunian sementara secara maksimal. Tujuan penelitian adalah untuk mengetahui model bantuan hunian sementara yang tepat pada pasca bencana yang diterapkan di lokasi pengungsian baik di Indonesia maupun di luar negeri. Metode penelitian menggunakan studi literatur dengan mengkomparasikan model hunian sementara dan studi maket sebagai perbandingan dimensi ukuran hunian. Hunian sementara adalah hunian yang dibutuhkan saat pasca bencana dan dapat diproduksi secara fabrikasi. Fabrikasi untuk hunian sementara berkaitan dengan sistem sambungan, material, pengemasan, pembongkaran, dan pendistribusian. Hal tersebut bertujuan untuk memaksimalkan bantuan di lokasi, memudahkan pemasangan, dan pendistribusian hunian sementara.

Kata kunci: hunian sementara, tahap transisi, fabrikasi

\section{PENDAHULUAN}

\section{Latar Belakang}

Negara Indonesia merupakan negara yang memiliki tingkat bencana yang sangat tinggi, secara geologis Indonesia rawan terhadap bencana gempa bumi, tsunami bahkan gunung meletus. Indonesia memiliki 3 lempeng tektonik yang aktif serta berada di jalur Ring of Fire, sehingga menimbulkan pergerakan dan pergeseran 
yang disebabkan oleh gempa (Mahira \& Hignasari, 2018; Santoso, Felecia, \& Panjaitan, 2016). Kebencanaan menurut Peraturan Kepala BNPB Nomor 8 Tahun 2011 adalah getaran atau guncangan yang terjadi di permukaan bumi yang disebabkan oleh tumbukan antar lempeng bumi, patahan aktif, aktivitas gunung api atau runtuhan batuan.

Akibat yang ditimbulkan dari bencana gempa bumi di Indonesia banyak memakan korban jiwa baik secara fisik maupun financial (tempat tinggal, gedung, fasilitas publik). Dampak bagi masyarakat yang selamat dari bencana terpaksa tinggal dan bermukim di barak pengusian dalam kurun waktu yang tidak singkat (Rizal \& Taivo, 2014). Maka, dari latar belakang tersebut diperlukan pengadaan hunian sementara (huntara) yang layak karena bantuan hunian tetap (huntap) dibutuhkan waktu pembangunan yang lama (Akhmad \& Fachruddin, 2008; Mahira \& Hignasari, 2018). Namun dewasa ini, Indonesia masih belum mampu dan tidak siap dalam penanganan bencana terutama dalam kategori huntara yang berkualitas, cepat dan layak. Dikarenakan Indonesia belum memiliki manajemen yang baik dan tepat untuk penanggulangan dan penanganan bencana (Badri \& Hubeis, 2008).

Maka huntara diperlukan karena para korban tidak boleh tinggal di tenda darurat dalam jangka waktu yang lama. Fungsi tenda darurat hanya diperuntukkan untuk fase emergency setelah bencana (Santoso et al., 2016). Pemerintah Indonesia belum sanggup memberikan bantuan huntara padahal pembangunan huntap dibutuhkan lebih dari 1 tahun. Dalam membangun huntara terdapat permasalahan yang perlu diperhitungkan yaitu pembangunan harus cepat, efisien, efektif dan material dapat digunakan kembali (re-use). Re-use yang dimaksud adalah meminimalisir sampah konstruksi setelah digunakan (Affisa, 2014; Mahira \& Hignasari, 2018). Huntara juga mempertimbangkan faktor aman, nyaman dan kuat terhadap angin maupun gempa selama proses pembangunan huntap (Hong, 2017; Rizal \& Taivo, 2014).

\section{METODE}

\section{Metode Penelitian}

Metode penelitian merupakan pedoman penelitian yang diambil secara runtun dan sesuai dengan fokus. Metode penelitian dapat dilakukan menggunakan pendekatan kualitatif, kuantitatif, dan campuran (Creswell, 2016).

Penelitian ini menggunakan metode komparasi literatur yang berkaitan huntara dan mock up atau maket. Metode kualitatif merupakan metode yang berkembang dengan pertanyaan terbuka serta analisis menggunakan cara secara tekstual dan gambar. Hal ini peneliti tidak memiliki orientasi teori secara eksplisit (Creswell, 2016). Maket digunakan pada saat menganalisis dengan tujuan untuk mengetahui besar dimensi model bantuan huntara yang berskala.

\section{TINJAUAN PUSTAKA}

\section{Terminologi Bencana dan Penanggulangan Bencana di Indonesia}

Definisi bencana pada Undangundang Nomor 24 Tahun 2007 tentang Penanggulangan Bencana Pasal 1 ayat 1 adalah peristiwa atau rangkaian peristiwa yang mengancam dan mengganggu kehidupan dan penghidupan masyarakat. Bencana terdiri dari bencana alam maupun non alam (Tondobala, 2011). Indonesia terdapat bencana alam yang disebabkan oleh gempa bumi, tsunami, gunung meletus, banjir, kekeringan, angin topan, tanah longsor, puting beliung, kebakaran dan kejadian luar biasa (wabah penyakit) (Carter, 1992; Sudrajat \& Wibowo, 2006).

Bencana alam gempa bumi yang terjadi di Indonesia menurut BNPB (Badan Nasional Penanggulangan Bencana) sejak tahun 1900 hingga 2016 sudah terjadi lebih dari 52.000 kali dengan berkekuatan lebih dari 5 SR. Pada tahun 2009 hingga 2018 bencana gempa bumi sudah terjadi sebanyak 143 kali. Adanya kejadian bencana BNPB melakukan serangkaian penanggulangan bencana, salah satunya adalah tanggap darurat yang telah diatur 
dalam Undang-undang Nomor 24 Tahun 2007. Tanggap darurat dilakukan secara cepat dan tepat dengan mengidentifikasi cakupan lokasi bencana, jumlah korban, kerusakan yang diakibatkan oleh bencana baik secara fisik maupun fungsi (Azmeri, Mutiawati, Al-huda, \& Mufiaty, 2017).

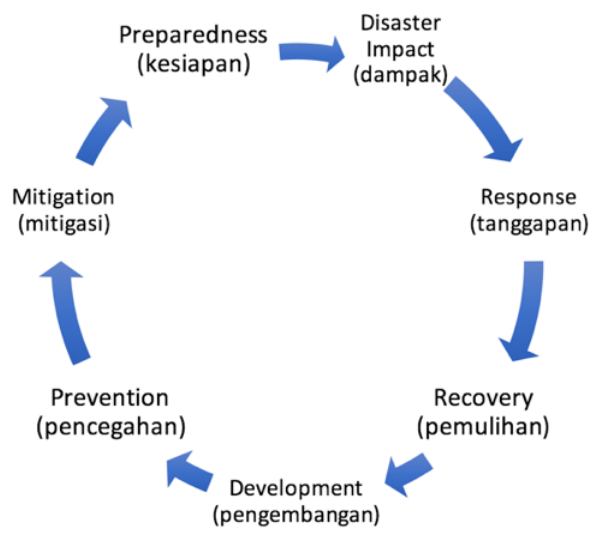

\section{Diagram 1: Siklus Manajemen} Kebencanaan

(Sumber: Carter, 1992, hal. xxiv)

Menurut (Carter, 1992) dalam buku "Disaster Management A Disaster Manager's Handbook", dijelaskan terdapat 6 unsur utama dalam tanggap darurat (diagram 1). Untuk masuk dalam kategori tanggap darurat adalah preparedness, response, dan recovery yang dilakukan secara cepat dan tepat. Tanggap darurat masuk dalam tahap response kemudian tahap recovery (diagram 2).

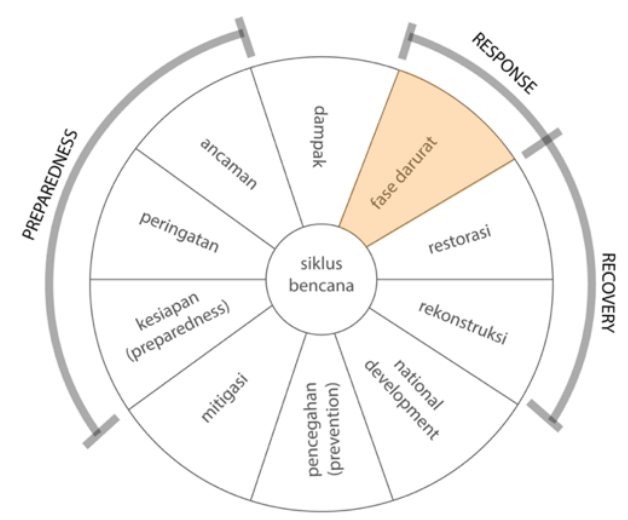

Diagram 2: Fokus Amatan terhadap
Disaster Management Cycle

(Sumber: Carter, 1992, hal. 52)
Pada tahap response diperlukan para ahli yang berkompeten. Salah satunya dalam bantuan hunian, hal tersebut dilakukan oleh para arsitek dan sipil dengan melakukan perekayasaan untuk struktur yang tahan bencana yaitu gempa.

\section{Terminologi Hunian Sementara}

Di tahap tanggap darurat diperlukan hunian yang layak bagi para korban yang bersifat sementara. Tujuan utama tahap tanggap darurat yaitu menyelamatkan korban bencana alam dengan melakukan penyelamatan korban hingga penyediaan huntara (Yustiningrum, Emilia, Sinaga, Yuliyanti, \& Nina Adriana, 2016). Huntara merupakan upaya menjembatani tahap tanggap darurat dan tahap rekonstruksi, dengan demikian dikategorikan sebagai tahap transisi (Affisa, 2014).

Permasalahan yang ada di Indonesia, pemerintah belum siap dan belum mampu menyediakan huntara. BNPB hanya masih mampu membantu dalam bentuk tenda darurat. Tenda darurat tidak cocok untuk digunakan dalam jangka panjang serta tidak manusiawi bagi para korban (Santoso et al., 2016). Menurut IFRC (Internasional Federation of Red Cross Foundation Red Crescent Societies) menjelaskan bahwa pengungsi yang berada di lokasi pengungsian selama 1 tahun diajurkan untuk diberikan huntara. Hal ini untuk tidak memperparah keadaan psikis dari korban, dapat dilihat skema pada (gambar 1).

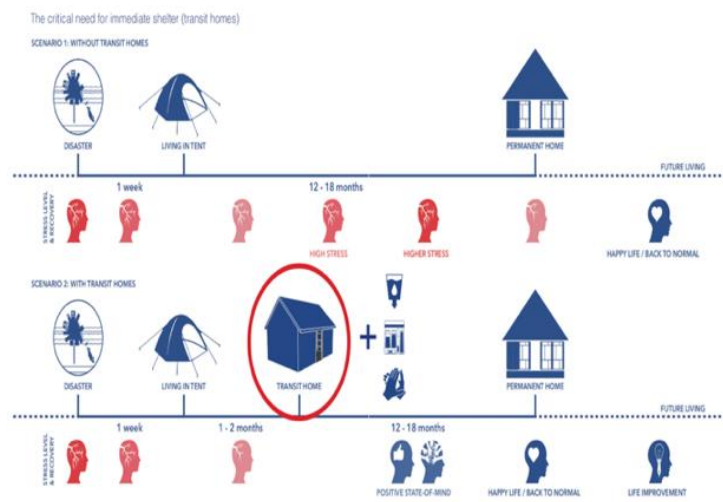

Gambar 1: Skenario Kondisi Psikis Korban Bencana

(Sumber: www.mercy.org.my diakses 15102018) 
Huntara merupakan solusi untuk tahap transisi, namun huntara dibutuhkan dengan cepat (Badri \& Hubeis, 2008; Putro, 2012) dan huntara merupakan kebutuhan yang penting untuk pasca bencana mengingat Indonesia adalah negara yang rawan akan bencana alam (Mahira \& Hignasari, 2018). Maka, harus mempertimbangkan keadaan psikis korban, serta pembangunan huntara dilakukan dengan cepat, efektif, efisien, tepat, dan hunian dapat digunakan kembali (re-use).

\section{Rekayasa Fabrikasi}

Pre-fabrikasi merupakan proses fabrikasi dengan tujuan untuk produksi secara massal dan solusi untuk perubahan arsitektur. Dengan adanya sistem fabrikasi dapat meminimalkan biaya (Ervianto, 2008; Jaganathan, Nesan, Ibrahim, \& Mohammad, 2013; Matcha, 2008; Suryandono \& Wong, 2012). Sistem prefabrikasi berkaitan dengan sistem modular yang mampu mereduksi durasi konstruksi dan manajemen dalam membangun (Ervianto, 2008). Sistem modular dilakukan dalam fabrikasi juga menunjang dalam pendistribusian pengiriman, hal ini berkaitan dengan pengemasan. Alat pendistribusian harus bisa menampung modular tersebut dengan pesawat, kapal, truk bahkan pick up. Penggunaan pick up untuk dapat menjangkau lokasi yang memiliki akses sempit (Noverti, Purwono, \& Martiningrum, 2014). Dikarenakan prefabrikasi memiliki konsep dasar yaitu 'people first' dalam pengaplikasiannya (Lin, Yu, Li, \& Zhou, 2013; Wang, Altan, \& Kang, 2015).

\section{Penanganan Pasca Bencana dengan Prefabrikasi}

Masa pasca bencana para korban bermukim dan menghuni pada barak-barak di pengungsian dalam waktu yang tidak singkat. Maka, dibutuhkan teknik dan sistem membangun hunian yang cepat dan kuat (Rizal \& Taivo, 2014). Penanganan pasca bencana pada tahap tanggap darurat memiliki kriteria yaitu dapat diterapkan dan dirangkai diberbagai lokasi, pengerjaan efektif, ekonomis, mudah dikemas, melalui proses fabrikasi, material

TERAKREDITASI : 36/E/KPT/2019

ISSN cetak 1410-6094 | ISSN online 2460-6367 dapat diperbaharui, serta fleksibel dalam penggunaan (Noverti et al., 2014).

Dengan melihat kasus huntara pada pasca bencana, hunian yang sesuai adalah temporary housing dikarenakan memiliki basis cepat dan ekonomis. Terdapat tipetipe temporary housing untuk pasca bencana sebagai berikut prefabrication house,container house, steel frame, reinforced concrete, paper house, dan tent (Hong, 2017). Untuk fasilitas publik dan pelayanan masyarakat di Indonesia pemerintah menyediakan tipe temporary housing yang kontainer (Prawata, 2012).

Sistem knock down atau perakitan dapat digunakan dalam pasca bencana. Knock down merupakan sistem konstruksi yang menggunakan struktur sambungan yang dapat dibongkar pasang sesuai dengan kebutuhan aktivitas penghuni serta memiliki konsep cepat, tahan gempa, efisien, murah, aman, dan nyaman, selain itu dapat meminimalisir pengeluaran (lowcost) (Akhmad \& Fachruddin, 2008).

\section{Kriteria Bahan Material untuk Huntara}

Kriteria bahan material untuk huntara didasarkan pada bahan yang kuat dan ringan baik untuk bagian rangka dan panel dinding. Huntara memiliki luas yang standar berdasarkan UNHCR yaitu $3 \mathrm{~m} \times 6$ $\mathrm{m}$ serta dapat menampung 5 orang. Menurut (Moon \& Lee, 2007) memaparkan bahwa huntara merupakan hunian yang tidak menggunakan struktur permanen namun memiliki tingkat kestandaran yang sesuai. Selain itu dapat dikerjakan secara modular dengan skala fabrikasi.

Bahan material yang digunakan untuk huntara menurut beberapa acuan penelitian sebelumnya terdapat bahan material untuk diterapkan pada bagian rangka adalah alumunium (Santoso et al., 2016; Irwan et al., 2016; Pero, 2014), baja (Moon \& Lee, 2007), baja galvanis (Santoso et al., 2016), kayu (Seike et al., 2018) dan FRP (Ikawati, 2019). Untuk bahan material pada bagian panel dinding menggunakan plastik (Santoso et al., 2016; Irwan et al., 2016), EPS sandwich panel (Santoso et al., 2016), metal komposit (Moon \& Lee, 2007), kayu (Seike et al., 
2018), membran (Pero, 2014) dan fiberglass reinforced plastics (Ikawati, 2019).

\section{Variabel dan Indikator Huntara}

Teori dasar yang digunakan dalam penelitian 'Rekayasa Fabrikasi Hunian Sementara untuk Pasca Bencana' adalah huntara dan fabrikasi. Kedua teori tersebut juga diperkuat oleh beberapa acuan untuk menambah nilai kualitas penelitian dan memberikan variabel yang didasarkan oleh efektif dan efisien, ekonomis, durability, dan safety.

Efektif dan efisien berkaitan dengan waktu pengerjaan huntara dengan melihat bahan material yang ringan serta dapat dikemas maupun dibongkar dengan mudah tanpa meninggalkan sampah konstruksi. Ekonomis yang dimaksud produk dapat diproduksi secara massal yang bersifat modular. Durability dapat dilihat dari ketahanan bahan terhadap bencana saat pasca dan anti karat. Safety berkaitan dengan kenyaman pengguna saat menggunakan huntara. Berikut adalah tabel variabel dan indikator penelitian rekayasa fabrikasi hunian sementara.

\section{Tabel 1: Variabel dan Indikator Penelitian}

\begin{tabular}{cll}
\hline & \multicolumn{1}{c}{ variabel } & \multicolumn{1}{c}{ indikator } \\
\cline { 2 - 3 } & & cepat \\
& ringan \\
& efektif & sistem \\
dan & bongkar \\
hunian & efisien & pasang \\
sementara & & minimal \\
& & sampah \\
& & konstruksi \\
\cline { 2 - 3 } & & pre-fabrikasi \\
& & low-cost \\
& & ekonomis \\
& & (murah) \\
& & transportasi \\
& & (distribusi) \\
& &
\end{tabular}

\begin{tabular}{ll}
\hline durability & $\begin{array}{l}\text { ketahanan } \\
\text { bahan } \\
\end{array}$ \\
& $\begin{array}{l}\text { finishing } \\
\text { bahan } \\
\text { anti karat }\end{array}$ \\
\hline safety & $\begin{array}{l}\text { kenyamanan } \\
\text { kuat (disaster } \\
\text { safety) }\end{array}$ \\
\hline sistem & modular \\
& sambungan \\
\hline
\end{tabular}

\section{Kerangka Pikir Penelitian}

Keterkaitan dengan teori yang dikaji dapat digambarkan skema kerangka pikir penelitian yang menjadi acuan dalam penelitian sebagai berikut (diagram 3),

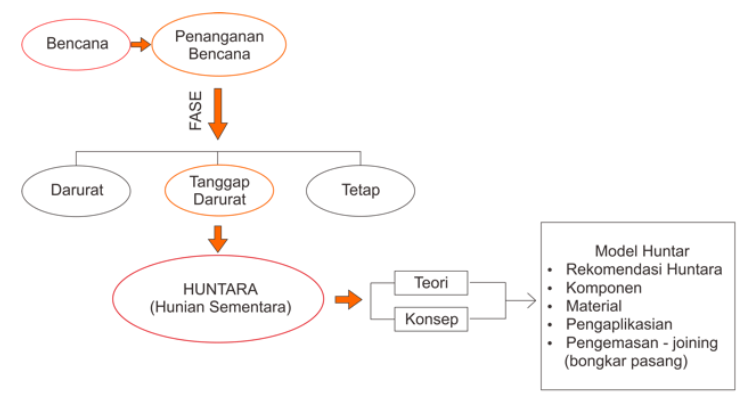

\section{Diagram 3: Kerangka Pikir Peneliti}

(Sumber: Peneliti)

\section{ANALISIS DAN PEMBAHASAN}

\section{Gambaran Umum Huntara}

Huntara merupakan kebutuhan dasar dan penting untuk hunian pada pasca bencana namun juga mempertimbangkan akan privasi pengungsi baik secara usia dan jenis kelamin. Huntara bersifat sementara sebagai tempat penampungan yang berfungsi sebagai tahap awal pemulihan serta memiliki durasi masa tingga di huntara selama 1-2 tahun. 


\section{Model Bantuan Huntara}

Bantuan huntara memiliki standar yang dikeluarkan oleh BNPB yaitu memiliki ukuran $3 \mathrm{~m}^{2}$ per orang, memiliki persyaratan keamanan dan kesehatan, memiliki aksebilitas terhadap fasilitas umum, dan menjamin privasi dan jenis kelamin. Menurut UNHCR memberikan standar huntara yaitu memiliki luas huntara minimal $18 \mathrm{~m}^{2}$ dan dapat menampung 5 orang per unit huntara.

Berikut adalah model bantuan huntara dari beberapa referensi baik dari dalam negeri maupun luar negeri. Terdapat 10 model yang dipilih, pemilihan huntara berdasarkan variabel dan indikator yang ditentukan. Huntara juga menggunakan sistem modular, fabrikasi, dan sistem sambungan tidak dilas (fix).

Tabel 2 : Model Bantuan Huntara

\begin{tabular}{|c|c|c|}
\hline peneliti & 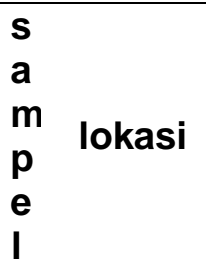 & huntara \\
\hline $\begin{array}{l}\text { Santos } \\
\text { o et al., } \\
2016\end{array}$ & A $\begin{array}{c}\text { (konsep } \\
\text { ) }\end{array}$ & \\
\hline
\end{tabular}

$\begin{aligned} & \text { Irwan } \\ & \text { et al., } \\ & 2016\end{aligned}$
B $\begin{gathered}\text { (konsep } \\ \text { ) }\end{gathered}$
$\begin{aligned} & \text { Moon \& } \\ & \text { Lee, }\end{aligned}$ C
2007

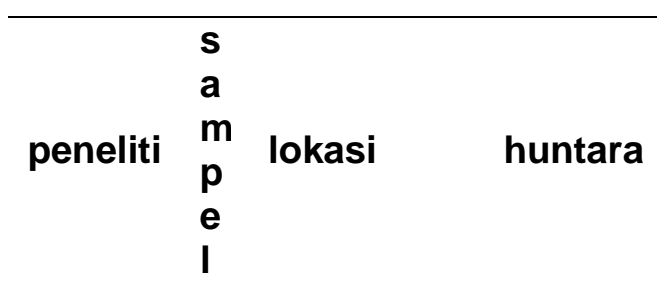

Moon \&
Lee, E Jepang
2007

\begin{tabular}{l}
$\begin{array}{l}\text { Moon \& } \\
\text { Lee, } \\
2007\end{array}$ \\
\hline Seike Jepang \\
et al., $\quad \mathrm{G}$ Jepang \\
2018
\end{tabular}

Pero, $\quad \mathrm{H}$ (konsep
2014

Mahira
$\&$
Hignas I Bali
ari,
2018

$\begin{array}{lc}\text { Ikawati, J } & \text { Indonesi } \\ 2019 & \text { a }\end{array}$

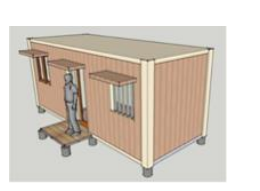

Pada tabel 2 dapat dijelaskan bahwa sampel A merupakan konsep dari huntara dengan luas $12 \mathrm{~m}^{2}$ yang dapat dikerjakan selama 1-2 jam. Bahan material yang digunakan alumunium (rangka), EPS sandwich panel (dinding), dan penutup atap menggunakan panel. Huntara sampel A dapat menahan angin dengan kecepatan $63 \mathrm{~km} / \mathrm{jam}$, anti karat, dan anti rayap. Huntara sampel B merupakan konsep yang dilakukan dengan menggunakan sistem sambungan rangka yang di bracket dan diperkuat dengan baut. Bahan material menggunakan alumunium (rangka), plastik (dinding), dan panel sebagai penutup atap. Huntara tahan terhadap karat dan bahan kimia.

Tesa Arsitektur Volume 18| Nomor 1 | 2020 
Sampel C merupakan huntara yang berada di Korea yang memiliki luas standar yaitu $18 \mathrm{~m}^{2}$. Bahan material yang digunakan adalah baja (rangka), metal komposit (dinding), dan atap galvanis. Huntara dapat difungsikan selama 6 bulan. Untuk sampel D, E, dan F merupakan huntara yang dibangun di Jepang dengan menggunakan jenis material sama dengan sampel $\mathrm{C}$ namun memiliki perbedaan pada luasan ditiap sampel. Sampel $D$ memiliki ukuran 5,4 m x 3,6 m (1-3 orang), sampel $E$ memiliki ukuran 5,4 m x $6 \mathrm{~m}$ (4-6 orang), dan sampel $F$ memiliki ukuran 5,4 $\mathrm{m} \times 7,2$ $m$ (> 7 orang). Ketiga sampel D,E, dan F memiliki durability yang cukup lama karena dapat difungsikan secara maksimal yaitu 2 tahun.

Huntara sampel G merupakan huntara yang menggunakan material kayu namun pengerjaan menggunakan sistem fabrikasi dan menggunakan baut (strap bolt) sebagai sistem sambungannya. Ukuran huntara adalah 12,74 m x 9,10 m, huntara dapat difungsikan untuk 2 unit atau dapat disebut sebagai huntra couple. Bangunan dapat difungsikan selama 2 tahun. Sampel $\mathrm{H}$ merupakan konsep yang memuncul pada tahun 2011 yang disebut dengan cmax shelter yang memiliki ukuran $7 \mathrm{~m} \times 3 \mathrm{~m}$. Huntara menggunakan bahan material yang ringan yaitu alumunium (rangka) dan membran sebagai dinding sekaligus atap, dengan sistem foldable. Waktu pengerjaan dapat ditempuh selama 11 menit dilakukan oleh 2 orang, serta dapat menahan angin dan hujan yang lebat.

Sampel I adalah huntara yang menggunakn bahan dari kontainer yang digunakan secara utuh, untuk huntara menggunakan ukuran 20 feet. Sistem sambungan menggunakan sistem folding. Huntara dapat tahan terhadap getaran atau gempa. Sampel J merupakan huntara yang dibangun oleh BPPT untuk bantuan gempa di Lombok pada tahun 2018. Bantuan tersebut merupakan bantuan dijadikan untuk tahap huntap setelah huntara dibangun dengan luasan $36 \mathrm{~m}^{2}$. Material yang digunakan yaitu FRP (fiberglass reinforced plastics) untuk bagian rangka, lantai, dinding serta menggunakan rangka atap baja ringan. Konsep bangunan tersebut yaitu fabrikasi modular yang mudah diterapkan dan memiliki berat komponen yang ringan.

\section{Ruang pada Huntara}

Huntara yang menjadi referensi memiliki kebutuhan ruang yang dibutuhkan oleh pengungsi. Kebutuhan ruang yang pokok adalah ruang tidur, ruang dapur, dan kamar mandi, tetapi ruang paling pokok dibutuhkan adalah ruang untuk beristirahat atau pemulihan dan tempat untuk berkumpul keluarga. Berikut adalah tabel kebuthan ruang pada huntara.

Tabel 3 : Kebutuhan Ruang di Huntara

\begin{tabular}{|c|c|c|c|c|c|}
\hline \multirow{4}{*}{$\begin{array}{c}\text { samp } \\
\text { el }\end{array}$} & \multicolumn{5}{|c|}{ Kebutuhan ruang } \\
\hline & \multirow{3}{*}{$\begin{array}{l}\text { rg. } \\
\text { tidur }\end{array}$} & \multirow{3}{*}{$\begin{array}{c}\text { Iivin } \\
g\end{array}$} & \multicolumn{3}{|c|}{ km } \\
\hline & & & dap & I & lain \\
\hline & & & ur & $\begin{array}{l}\text { W } \\
C\end{array}$ & lain \\
\hline$A$ & V & V & - & - & - \\
\hline$B$ & V & V & - & - & - \\
\hline $\mathrm{C}$ & V & V & V & - & - \\
\hline $\mathrm{D}$ & V & V & v & V & v \\
\hline$E$ & $\mathrm{~V}$ & V & v & $\mathrm{V}$ & $\mathrm{V}$ \\
\hline$F$ & $\mathrm{~V}$ & V & V & V & $\mathrm{v}$ \\
\hline $\mathrm{G}$ & V & V & V & V & V \\
\hline $\mathrm{H}$ & V & V & - & - & - \\
\hline I & V & V & V & V & V \\
\hline J & $\mathrm{V}$ & V & V & V & - \\
\hline
\end{tabular}

Pada tabel 3 dapat dilihat bahwa kebutuhan ruang yang dibutuhkan pada kedelapan model bantuan huntara adalah ruang tidur dan living, karena fungsi dari living juga dapat difungsikan sebagai ruang komunal. Terdapat fungsi ruang sebagai lain-lain, fungsi ruang tersebut difungsikan sebagai ruang entrance yang berada di dalam ruang sebelum memasuki ruang komunal. Ruang tersebut terdapat 
pada sampel D, E, F, dan G, keempat huntara tersebut menggunakan ruang tersebut karena faktor budaya negara Jepang dan Korea. Ruang tersebut difungsikan sebagai ruang transisi antara ruang luar dan ruang dalam. Berbeda dengan ruang lain-lain pada sampel I, ruang tersebut merupakan ruang teras.

Kesepuluh huntara tidak semuanya menggunakan ruang dapur dan kamar mandi (WC) di dalam. Karena konsep huntra pertimbangan akan akibat yang ditimbulkan antara lain kebakaran yang disebabkan oleh dapur dan penyakit yang disebabkan sanitasi yang kurang higinis pada area kamar mandi. Maka, beberapa huntara menggunakan fasilitas dapur dan kamar mandi bersama atau komunal.

\section{Sistem Fabrikasi pada Huntara}

Fabrikasi yang digunakan pada huntara dapat mempengaruhi sistem sambungannya. Sistem fabrikasi dapat diproduksi dengan cepat, efesien, dan efektif. Dari kesepuluh model bantuan huntara dapat diketahui terdapat 5 huntara yang menggunakan sistem sambungan bracket yang diperkuat dengan baut, menggunakan strap bolt, sistem foldable, sistem folding, dan interlock. Berikut tabel penggunaan sistem pada membuat dan membangun huntara beserta durasi.

Tabel 4 : Sistem pada Huntara

\begin{tabular}{cccc}
\hline $\begin{array}{c}\text { samp } \\
\text { el }\end{array}$ & sistem & joining & $\begin{array}{c}\text { dura } \\
\text { si }\end{array}$ \\
\hline A & $\begin{array}{c}\text { fabrikas } \\
\text { i } \\
\text { modula } \\
\end{array}$ & - & $\begin{array}{c}1-2 \\
\text { jam }\end{array}$ \\
& $\begin{array}{c}\text { fabrikas } \\
\text { i } \\
\text { B }\end{array}$ & bracket \& \\
& $\begin{array}{c}\text { modula } \\
\text { baut }\end{array}$ & - \\
\hline C & $\begin{array}{c}\text { fabrikas } \\
\text { i }\end{array}$ & - & - \\
\hline
\end{tabular}

\begin{tabular}{|c|c|c|c|}
\hline D & $\underset{\mathrm{i}}{\text { fabrikas }}$ & - & - \\
\hline$E$ & $\begin{array}{c}\text { fabrikas } \\
\text { i }\end{array}$ & - & - \\
\hline$F$ & $\underset{\mathrm{i}}{\text { fabrikas }}$ & - & - \\
\hline G & $\underset{i}{\text { fabrikas }}$ & strap bolt & - \\
\hline $\mathrm{H}$ & $\begin{array}{c}\text { fabrikas } \\
i\end{array}$ & foldable & $\begin{array}{c}11 \\
\text { menit }\end{array}$ \\
\hline I & $\begin{array}{c}\text { fabrikas } \\
\text { i } \\
\text { kontain } \\
\text { er }\end{array}$ & $\begin{array}{c}\text { folding } \\
\text { (dibaut) }\end{array}$ & - \\
\hline$J$ & $\begin{array}{c}\text { fabrikas } \\
\text { i } \\
\text { modula } \\
r\end{array}$ & $\begin{array}{c}\text { interlock } \\
\text { (angkur, } \\
\text { pelat) }\end{array}$ & - \\
\hline
\end{tabular}

Durasi yang dapat diketahui hanya pada sampel A dan sampel $H$. Huntara sampel $\mathrm{H}$ pemasangan hanya dipatok 11 menit saja dikarenakan model huntara memiliki sistem foldable atau lipat.

\section{Bahan Material Huntara}

Bahan material yang dipergunakan pada model bantuan huntara menggunakan bahan material yang mudah digunakan, ringan, dan dapat diproduksi secara massal dengan mempertimbangkan kekuatan dan durability (keawetan). Berikut penggunaan bahan material pada kesepuluh model bantuan huntara. 
Tabel 5 : Bahan Material Huntara

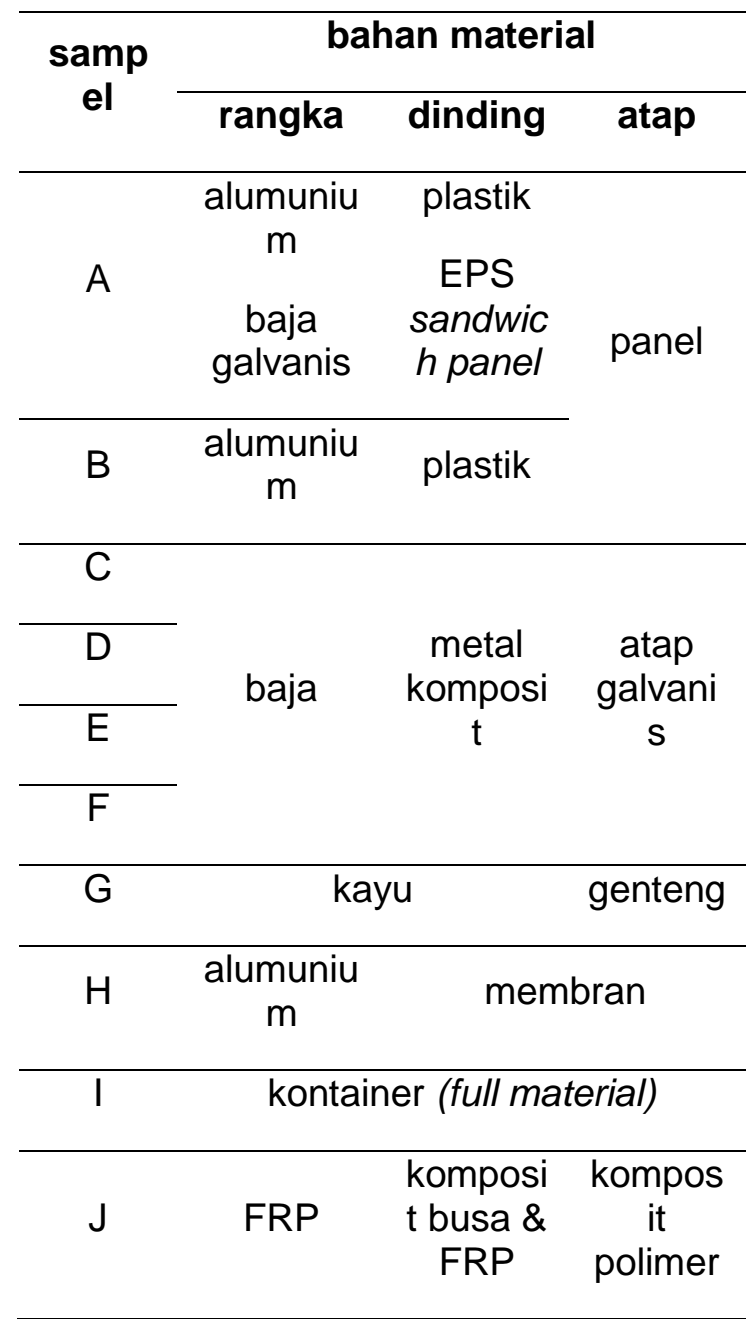

Bahan material yang digunakan merupakan hasil fabrikasi kecuali yang digunakan pada sampel G. Sampel G menggunakan material kayu pada bagian rangka dan dinding huntara. Mengingat material kayu memiliki harga yang mahal dan produksi berasal dari alam, sehingga sampel $\mathrm{G}$ lebih bisa dijadikan hunian tetap ditahap selanjutnya.

Sifat material yang ringan sangat dibutuhkan untuk huntara, agar saat membangun huntara dilokasi tidak perlu membutuhkan personil banyak.

\section{Analisis Model Bantuan Huntara}

Setelah dilakukan penganalisis dengan menggunakan mock up atau maket berskala 1:50 pada kesepuluh model bantuan huntara. Dapat diketahui ukuran dimensi setiap model huntara. Analisis dilakukan berdasarkan syarat standar badan internasional UNHCR untuk bantuan huntara yaitu memiliki luasan $18 \mathrm{~m}^{2}$ dan dapat menampung 4 hingga 5 orang (1 keluarga inti) atau 1 orang per $3 \mathrm{~m}^{2}$.

Dari kesepuluh model bantuan huntara terdapat hunian yang memiliki kriteria tersebut serta varibel dan indikator yang sudah ditentukan (tabel 1).

\section{Tabel 6 : Analisis Model Bantuan Huntara}

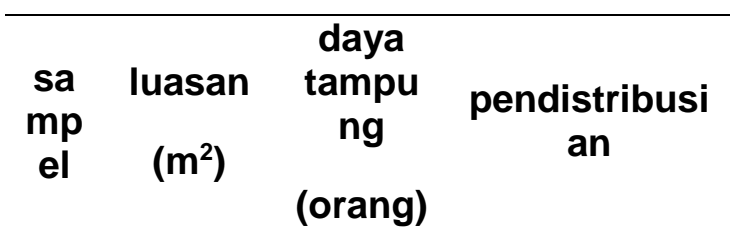

\begin{tabular}{|c|c|c|c|c|c|c|}
\hline A & 12 & v & 4 & v & $\begin{array}{c}\text { pick up, } \\
\text { truk }\end{array}$ & v \\
\hline B & 18,9 & v & 5 & v & $\begin{array}{c}\text { pick up, } \\
\text { truk }\end{array}$ & v \\
\hline C & 18 & v & 4 & v & truk & $\mathrm{v}$ \\
\hline $\mathrm{D}$ & 19,4 & $\mathrm{v}$ & $1-3$ & $x$ & - & - \\
\hline$E$ & 32,4 & $x$ & $4-6$ & $x$ & - & - \\
\hline$F$ & 38,8 & $x$ & $>7$ & $x$ & - & - \\
\hline$G$ & $\begin{array}{c}115 \\
9\end{array}$ & $x$ & 10 & $x$ & - & - \\
\hline $\mathrm{H}$ & 21 & $v$ & 5 & v & $\begin{array}{c}\text { pick up, } \\
\text { truk, } \\
\text { kapal, } \\
\text { pesawat }\end{array}$ & $\mathrm{v}$ \\
\hline 1 & 14,7 & v & 4 & v & $\begin{array}{c}\text { truk } \\
\text { kontainer }\end{array}$ & $x$ \\
\hline $\mathrm{J}$ & 35 & $x$ & 5 & $\mathrm{v}$ & - & - \\
\hline
\end{tabular}

Pada tabel 6 dapat dilihat model bantuan huntara dapat disotir menjadi lebih kecil menjadi 4 model bantuan huntara yang berdasarkan luasan, daya tampung, dan pendistribusian. Analisis mengambil sampel yang memiliki luasan $12 \mathrm{~m}^{2}$ hingga $21 \mathrm{~m}^{2}$. 
Pada sampel A termasuk dalam kriteria dikarenakan memiliki konsep pengemasan dan pengerjaan dilapangan cepat (tabel 4), serta pendistribusian huntara menggunakan alat transportasi kecil yang dapat menjangkau tempat lokasi yang sempit. Pada sampel $\mathrm{H}$ bila dilihat dari ukuran luasan, sampel $\mathrm{H}$ lebih besar dari standar UNHCR yaitu $21 \mathrm{~m}^{2}$. Namun sampel tersebut memiliki keunggulan dalam konsep yang praktis dan dapat dikemas maupun diterapkan dalam waktu 11 menit (tabel 4). Dalam hal pendistribusian sampel $\mathrm{H}$ dapat menggunakan semua jenis alat transportasi. Untuk sampel I tidak dimasukkan dalam kriteria huntara dikarenakan sampel tersebut terbuat dari kontainer yang notabene dalam pendistribusian membutuhkan 1 truk besar yaitu 1 truk untuk 1 kontainer. Hal tersebut merupakan kendala yang sangat mendasar dikarenakan beberapa tempat lokasi pengungsian memiliki akses yang sulit dan tidak dapat dilalui dengan menggunakan truk berukuran besar. Maka sampel I hanya dapat digunakan untuk fasilitas pelayanan masyarakat seperti klinik, puskesmas, dan kantor pemerintah sementara.

\section{PENUTUP}

\section{Kesimpulan}

Hunian sementara (huntara) sangat dibutuhkan untuk membantu korban pasca bencana. Hunian juga harus memenuhi standar kebutuhan baik daya tampung, ruang yang paling dibutuhkan bahkan hingga pencapaian atau distribusi hunian tersebut ke lokasi pengusian. Standar huntara dari UNHCR sudah banyak diterapkan namun masih terkendala akan kepraktisan hunian yaitu pengemasan dan pengakutan. Hasil dari analisis kesepuluh model bantuan huntara dapat ditarik kesimpulan bahwa huntara yang paling mendasar dibutuhkan adalah sebagai berikut,

1. Memiliki ruang yang dibutuhkan paling utama yaitu ruang tidur dan living.
2. Dapat menampung sebanyak 4 hingga 5 orang atau keluarga inti dalam 1 unit huntara.

3. Bahan material yang digunakan untuk huntara bersifat fabrikasi dan memiliki keawetan (durability) yang lama sekitar 1-2 tahun penggunaan di lapangan.

4. Pendistribusian huntara dapat didistribusikan menggunakan alat transportasi paling kecil yaitu mobil pick up dan truk kecil.

5. Pemasangan dan pembongkaran huntara tidak meninggalkan sampah kontruksi.

\section{Saran}

Saran untuk penelitian selanjutnya adalah model huntara dapat diperdalam lagi untuk menemukan huntara yang tepat, efesien, efektif, dan cepat terutama dibagian sistem sambungan huntara. Sistem sambungan yang praktis dan mudah dipahami dapat memudahkan pemasangan dan pembongkaran saat di lokasi pengungsian. Serta kedepan model bantuan huntara dapat diproduksi secara massal dan dapat difungsikan dengan cepat tanpa mempersulit korban pasca bencana.

\section{Ucapan Terimakasih}

Artikel ini merupakan bagian dari tesis yang diselesaikan penulis pada Program Magister Arsitektur Fakultas Teknik Universitas Gadjah Mada. Ucapan terimakasih disampaikan kepada semua civitas akademik Universitas Gadjah Mada.

\section{DAFTAR PUSTAKA}

Affisa, F. S. (2014). Efektivitas Kawasan Hunian Sementara Sebagai Media Pemulihan Pengungsi Pasca Bencana Merapi 2010 Studi Kasus Pada Kawasan Hunian Sementara Plosokerep, Gondangpusung, Banjarsari, dan Gondanglegi. Universitas Gadjah Mada.

Akhmad, A. G., \& Fachruddin, P. A. (2008). Disain Rumah Tinggal Konstruksi

Tesa Arsitektur Volume 18| Nomor 1| 2020 
"Knock Down" (Tinjauan Khusus Penggunaan Prefabrikasi Lokal). Jurnal SMARTek, 6(1), 18-28.

Azmeri, Mutiawati, C., Al-huda, N., \& Mufiaty, H. (2017). Disaster Recovery Indicators of Housing Reconstruction: The Story of Post Tsunami Aceh, Indonesia. International Journal of Disaster Management, 1(1), 35-45.

Badri, M., \& Hubeis, M. (2008). Pemberdayaan Komunikasi Pemuka Pendapat dalam Penanganan Bencana Gempa Bumi Di Yogyakarta ( Kasus Kabupaten Bantul ). Jurnal Komunikasi Pembangunan, 06(1), 5571.

Carter, W. N. (1992). Disaster Management: A Disaster Manager's Handbook.

Creswell, J. W. (2016). Research Design Pendekatan Metode Kualitatif, Kuantitatif, dan Campuran (4th ed.). PUSTAKA PELAJAR.

Ervianto, W. I. (2008). Potensi Penggunaan Sistem Modular Pada Proyek Konstruksi. Jurnal Teknik Sipil, 8(2), 170-183.

Hong, Y. (2017). A study on the condition of temporary housing following disasters: Focus on container housing. Frontiers of Architectural Research, 6(3), 374383.

https://doi.org/10.1016/j.foar.2017.04. 005

Ikawati, Yuni. 2019. Hunian Tetap Tahan Gempa. Jakarta: Kompas. (27 Mei 2019), hal. 10

Irwan, M., Ekasiwi, S.N.N., \& Bararatin, Kirami. (2016). Bangunan Portabel Sebagai Solusi Kebutuhan Hunian Temporer yang Layak Huni. Jurnal Sains dan Seni ITS, 5(2).

Jaganathan, S., Nesan, L. J., Ibrahim, R., \& Mohammad, A. H. (2013). Integrated design approach for improving architectural forms in industrialized building systems. Frontiers of Architectural Research, 2(4), 377-386. https://doi.org/10.1016/j.foar.2013.07. 003

Lin, B., Yu, Q., Li, Z., \& Zhou, X. (2013). Research on parametric design method for energy efficiency of green building in architectural scheme phase. Frontiers of Architectural Research, 2(1), $11-22$. https://doi.org/10.1016/j.foar.2012.10. 005

Mahira, E. D., \& Hignasari, V. (2018). Konsep Mandala Pada Rancangan Limbah Kontainer Untuk Hunian Sementara Korban Bencana Alam Di Bali. Vitruvian, 7(2), 77-86.

Matcha, H. (2008). Architectural Design with Parametric Modeling \& Customized Mass Production: Explorations and Case Studies in Architectural Design and Production Methods.

Moon, J., \& Lee, S. (2007). A Study on the Planning Method of Temporary Residences for Refugees Following a Disaster - Focused on Korean Temporary Residences -. JAABE, 6(November), 251-258.

Noverti, R. S., Purwono, E. H., \& Martiningrum, I. (2014). Perancangan Bangunan Instan Fabrikasi. Jurnal Mahasiswa Jurusan Arsitektur, 2(2). Retrieved from http://arsitektur.studentjournal.ub.ac.id /index.php/jma/article/view/42

Peraturan Kepala BNPB Nomor 8 Tahun 2011 tentang Standardisasi Data Kebencanaan

Pero, James. (2014). Housing the Displaced. Diakses dari https://www.asme.org/engineeringtopics/articles/global-impact/housingthe-displaced?cm sp=Home- HomeContent- -Housing-theDisplaced pada tanggal 20 Februari 2019 pukul 14.33 WIB.

Prawata, A. (2012). Rancangan Berkelanjutan Rumah Kargo Kontainer Dengan Sistem Modular di Jakarta Utara. ComTech, 3(2), 1007-1013. 
Putro, H. P. (2012). Pembangunan Huntara Mentawai. Yogyakarta: Calpulis. Pasca Bencana Merapi Di Kabupaten Sleman. Universitas Gadjah Mada.

Rizal, F., \& Taivo. (2014). Desain Permodelan Sambungan Beton Precast Pada Perumahan Tahan Gempa Di Indonesia Berbasis Knockdown System. Jurnal Teknik POMITS, 3(1), 1-4.

Santoso, W. E., Felecia, \& Panjaitan, T. W. S. (2016). Pembuatan Prototipe Hunian Sementara untuk Pengungsi di Indonesia. Jurnal Titra, 4(2), 235-242.

Seike, T., Kim, Y., Hosaka, Y., Ida, S., \& Masuda, T. (2018). Intraregional Reuse of Emergency Temporary Housing in Japan. Sustainable Cities and Society, 42, 650-662. http://doi.org/10.1016/i.scs.2017.11.00 1

Sudrajat, \& Wibowo, S. (2006). Pemahaman Tentang Menejemen Bencana Alam Siswa Sekolah Menengah Pertama, 168-189.

Suryandono, A., \& Wong, P. (2012). Locally Based Approach For Prefabricated Housing - Case Study: Indonesia. In ACSA Fall Conference (pp. 195-199).

Tondobala, L. (2011). Pendekatan Untuk Menentukan Kawasan Rawan Bencana Di Pulau Sulawesi. Jurnal Sabua, 3(3), 40-52.

Undang-undang Nomor 24 Tahun 2007 tentang Penanggulangan Bencana dan Badan Nasional Penanggulangan Bencana

Wang, X., Altan, H., \& Kang, J. (2015). Parametric study on the performance of green residential buildings in China. Frontiers of Architectural Research, 4(1), 56-67. https://doi.org/10.1016/j.foar.2014.06. 007

Yustiningrum, Emilia, R., Sinaga, L. C., Yuliyanti, R., \& Nina Adriana. (2016). Bencana Alam, Kerentanan dan Kebijakan di Indonesia: Studi Kasus Gempa Padang dan Tsunami 